\title{
Constructing Heritage in Early Soviet Central Asia: The Politics of Memory in a Revolutionary Context
}

DOI:

10.1353/imp.2016.0087

\section{Document Version}

Accepted author manuscript

Link to publication record in Manchester Research Explorer

\section{Citation for published version (APA):}

Tolz, V., \& Gorshenina, S. (2017). Constructing Heritage in Early Soviet Central Asia: The Politics of Memory in a Revolutionary Context. Ab Imperio, 2016(4), 77-115. https://doi.org/10.1353/imp.2016.0087

\section{Published in:}

Ab Imperio

\section{Citing this paper}

Please note that where the full-text provided on Manchester Research Explorer is the Author Accepted Manuscript or Proof version this may differ from the final Published version. If citing, it is advised that you check and use the publisher's definitive version.

\section{General rights}

Copyright and moral rights for the publications made accessible in the Research Explorer are retained by the authors and/or other copyright owners and it is a condition of accessing publications that users recognise and abide by the legal requirements associated with these rights.

\section{Takedown policy}

If you believe that this document breaches copyright please refer to the University of Manchester's Takedown Procedures [http://man.ac.uk/04Y6Bo] or contact uml.scholarlycommunications@manchester.ac.uk providing relevant details, so we can investigate your claim.

\section{OPEN ACCESS}




\section{PROJECT MUSE}

Constructing Heritage in Early Soviet Central Asia: The Politics of Memory in a Revolutionary Context

Svetlana Gorshenina, Vera Tolz

Ab Imperio, 4/2016, pp. 77-115 (Article)

Published by Ab Imperio

DOI: https://doi.org/10.1353/imp.2016.0087

$\Rightarrow$ For additional information about this article https://muse.jhu.edu/article/650984 


\section{CONSTRUCTING HERITAGE}

IN EARLY SOVIET CENTRAL ASIA:

\section{The Politics of Memory in a Revolutionary Context*}

At the time when the Bolshevik regime was consolidating its power over the former Russian colony of Turkestan, in 1921 the local Council of People's Commissars issued a decree on the preservation of "monuments of Islamic architecture." Using the new regime's terminology, Turkestan's main governmental body suggested that the preservation work should be carried out "as a special priority and with a shock worker's effort" (vneocherednogo sverkhudarnogo poriadka). ${ }^{1}$ The Commission for the Preservation of Monuments of Antiquity and Art, set up in the previous year in Samarkand, a city particularly rich with such "monuments," agreed that "the proletariat, once it had come to power, could not look with indifference on the destruction of these treasures of art."2 At first glance it seems paradoxical that the

* The article is based on the paper presented at the Fourth European Congress on World and Global History (Paris, September 4-5, 2014), the panel "The Construction of the 'Cultural Heritage' on the Russian and Soviet Peripheries: Between Archaeology and the 'Protection of Monuments'." The authors would like to thank the anonymous reviewers and the editors of $A b$ Imperio for their valuable comments and suggestions.

${ }^{1}$ Materialy Samarkandskoi Kommissii po okhrane pamiatnikov stariny i iskusstva, 1920-1921 // The St. Petersburg Branch of the Archive of the Russian Academy of Sciences (henceforth A RAN (SPb)). F. 68. Op. 1. D. 443. L. 27; the Central State Archive of the Republic of Uzbekistan (henceforth TsGA RUz). F. R-1. Op. 1. D. 92. L. 39.

${ }^{2}$ A RAN (SPb). F. 68. Op. 1. D. 443. L. 69ob. 
regime, whose aim was to build a new society by repudiating the past and eradicating its ills, such as religion, would attribute such importance to the preservation of medieval monuments, particularly those defined through their association with religion. This article will address this paradox by analyzing discourses, policies, and practices associated with the construction of cultural and historical heritage in early Soviet Central Asia.

Critical Heritage Studies has been a burgeoning field of inquiry in the past forty years. ${ }^{3}$ Using examples from different national and imperial contexts, scholars have demonstrated that the transformation of various architectural structures and artifacts into "historical monuments" and "cultural heritage" has been a conscious and deliberate process, reflecting both discourses and practices of actors pursuing specific goals. ${ }^{4} \mathrm{~A}$ modern notion of "monument preservation" began to take shape in Europe in the course of the French Revolution and the Napoleonic Wars. Initially scholars focused on nationalism, patriotism, and nostalgia for the past as the driving forces behind preservation activities. Only more recently has a major impact of European imperialism and colonialism on heritage making and preservation begun to be acknowledged. ${ }^{5}$

In Russian Studies, research on practices of heritage making is still a relatively new field, with most scholarship focusing on the developments

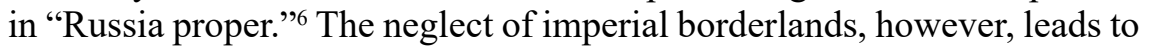
underplaying the role of imperialism and colonialism in the consideration of how the very notion of "culture" has been formulated within the Rus-

${ }^{3}$ See, in particular: David Lowenthal. The Past is a Foreign Country. Cambridge, 1985; Robert Hewison. The Heritage Industry: Britain in a Climate of Decline. London, 1987; Patrick Wright. On Living in an Old Country: The National Past in Contemporary. London and New York, 1991; Raphael Samuel. Theatres of Memory: Past and Present in Contemporary Culture. London and New York, 1994; Dominique Poulot. Musée, nation, patrimoine, 1789-1815. Paris, 1997.

${ }^{4}$ Laurajane Smith. Uses of Heritage. London and New York, 2006; Marie Louise Sørensen, and John Carman. Heritage Studies: Methods and Approaches. London, 2009; Rodney Harrison. Heritage: Critical Approaches. London and New York, 2013.

${ }^{5}$ Astrid Swenson. Introduction // Astrid Swenson, and Peter Mandler (Eds.). From Plunder to Preservation. Britain and the Heritage of Empire, c. 1800-1940. Oxford, 2013. Pp. 6-12; Astrid Swenson. The Rise of Heritage: Preserving the Past in France, Germany and England, 1789-1914. Cambridge, 2013. Pp. 5-7.

${ }^{6}$ See, in particular, Andreas Schönle. Architecture of Oblivion: Ruins and Historical Consciousness in Modern Russia. DeKalb, 2011; Idem. Broken History and Crumbling Stones: The Romantic Conception of Architectural Preservation and Its Legacy // Slavic Review. 2012. Vol. 71. No. 4. Pp. 745-765; Catriona Kelly. Socialist Churches: Heritage Preservation and "Cultural Buildings" in Leningrad, 1924-1949 // Slavic Review. 2012. Vol. 71. No. 4. Pp. 792-823. 
sian and Soviet states. ${ }^{7}$ Experiences in Central Asia are crucial for filling the gaps in our understanding of heritage construction in the Russian and Soviet imperial, colonial, and multiethnic contexts. On the one hand, the Russian discourse of preservation as it was formed, partly in response to local practices, in the late imperial period and continued into the Soviet era fitted with the pan-European tendency of representing the current cultures and societies of Europe's colonial domains as inferior, while at the same time acknowledging the cultural greatness of some regions of "the East" in the past. Yet the Russian discourse also had its specific dimension. As we shall see, following the Russian conquest of Central Asia in the 1860s, this colonial periphery was discursively constructed by leading preservationists as the locus of the most important "historical monuments" and "cultural heritage" of the entire Russian and later Soviet state. This claim was uncommon in the European context of the time, as the dominant European discourse tended to claim superiority of the metropole over the colonies in terms of the value of historical monuments to be found there. ${ }^{8}$

The period analyzed in this article - from the 1917 Revolution to the end of Stalin's Cultural Revolution in the early 1930s, but with an introductory account of prerevolutionary developments - allows us to assess the continuities and breaks across the 1917 divide and, in the area of the politics of culture, the extent to which the Soviet Union was both the heir to the tsarist empire and a significant innovator. By analyzing highly contradictory, eclectic narratives of what constitutes "historical monuments," discourse and practices of their preservation, as well as personalities and institutions involved in preservation activities, we will shed light on (1) the ways historical memory was actively mobilized in the service of a regime that had a

${ }^{7}$ For insightful reflections on this issue, see, in particular, Nicholas Dirks. Introduction: Colonialism and Culture // Nicholas Dirks (Ed.). Colonialism and Culture. Ann Arbor, 1992. P. 3. The few publications that acknowledge the relationship between preservation, colonialism, imperial policies and the notion of culture in relation to Russian Empire and the USSR are S. Gorshenina. Turkomstaris - Sredazkomstaris - Uzkomstaris: Formirovanie institutsii i etnotsentricheskii razdel kul'turnogo naslediia Srednei Azii // Etnograficheskoe obozrenie. 2013. No. 1. Pp. 52-68; Eadem. Samarkand and its Cultural Heritage: Perceptions and Persistence of the Russian Colonial Construction of Monuments // Central Asian Survey. 2014. Vol. 33. No. 2. Pp. 246-269; Eadem. "Les faiseurs de patrimoine". Transformation des vestiges en "monuments historiques" en situation coloniale, le cas du Turkestan russe (années 1860-1910) / Habilitation à diriger des recherches. Paris, 2016; Ekaterina Pravilova. Contested Ruins: Nationalism, Emotions, and Archaeology at Armenian Ani, 1892-1918 // Ab Imperio. 2016. No. 1. Pp. 69-101; Louise McReynolds. Nikolai Marr: Reconstructing Ani as the Imperial Ideal // Ab Imperio. 2016. No. 1. Pp. 102-124.

${ }^{8}$ Swenson. Introduction. P. 9. 
contradictory relationship with the "past" (proshloe); (2) the reasons behind and the political implication of the changing understanding of the notion of "national culture" in the early Soviet period; and (3) the relationship between the Soviet regime's broad anti-imperial and anticolonial claims, on the one hand, and local discourses as well as practices on the ground, on the other. Before presenting our case study, we will look at the scholarly debates that are directly relevant to the issues we are addressing.

\section{Relevant Scholarly Debates}

The tension between the revolutionary urge to repudiate the past and preservationist impulses of the Soviet policies has been noted by scholars such as Richard Stites, Catriona Kelly, and Jeremy Smith, as well as the authors of this article. They point to the inconsistency of the decisions of the early Soviet government and the continuity of cadres in the cultural institutions with origins in the prerevolutionary period. ${ }^{9}$ Yet the complexity of the uses of the past in the Russian and Soviet intellectual and political traditions requires further investigation.

Andreas Schönle's work is a pioneering attempt to systematically explore such complexity, analyzing attitudes toward historical ruins and preservation in Russia from the imperial era to the present day. Schönle postulates "the opposition between a western embrace and Russian disregard for the importance of ruins...", arguing that "the awareness that Western Europe is much more committed to heritage preservation than Russia... had the perverse effect of turning respect for architectural antiquities into a moral trait of the Westernized elites, a quality thus perceived as alien to Russian national identity." 10 Claiming Russia's overall "hostility to preservation," he suggests that "after the revolution, once the country had committed to a particularly radical version of modernity, the ruin began to serve its function as a nostalgic site of escape from an ideologically inflected reality..." and of "resistance to the Soviet interpretation of modernity." 11

\footnotetext{
${ }^{9}$ Richard Stites. Utopian Vision and Experimental Life in the Russian Revolution. New York, 1989. Pp. 76-8; Kelly. Socialist Churches; Jeremy Smith. The Bolsheviks and the National Question, 1917-1923. Basingstoke, 1999. Pp. 169-171. See also Vera Tolz. "Russia's Own Orient": The Politics of Identity and Oriental Studies in the Late Imperial and Early Soviet Periods. Oxford, 2011. Pp. 134-167, and Gorshenina. Turkomstaris. Pp. 52-68.

${ }^{10}$ Schönle. Broken History and Crumbling Stones. P. 764; Idem. Architecture of Oblivion. P. 221.

${ }^{11}$ Schönle. Architecture of Oblivion. P. 229. 
Most of Schönle's sources are narratives produced by Russian literary figures. These provide evidence about particular visions of Russian identity that these figures promoted. They say little, however, about attitudes and practices of those actors who were directly involved in preserving "historical monuments," above all members of various preservation commissions and societies, most of whom were scholars, particularly archaeologists, and government officials. The rich documentation left by these institutions paints a picture different from the one we find in Schönle's account. ${ }^{12}$ This documentation suggests that, since the second half of the nineteenth century, when heritage preservation became a particularly significant element of nation building and colonial projects, Russian approaches to preservation were developed in line with the trends in Europe, rather than being an outlier. Members of the preservation commissions and societies were guided by the same set of assumptions as their counterparts elsewhere in Europe, similarly adapting their approaches to specific local conditions. ${ }^{13}$

In nineteenth-century Europe, the preservation of what started to be defined as "a historical [or ancient] monument" gradually became important for the development of the concept of "Civilization." "Civilized nations" were expected not only to possess but also to preserve monuments from the past. In this period, the ability to appreciate the historical and aesthetic values of "monuments" was perceived to be a sign of the nation's "civilizational level." This appreciation was alleged to be a feature of European

${ }^{12}$ This article's account is based on the analysis of rich documentation produced by the main preservation bodies in Central Asia; the Sovnarkom and Narkompros of Turkestan and Uzbekistan; the Academy of Sciences and the Academy of the History of Material Culture in Petrograd / Leningrad; the Glavmusei of the RSFSR Narkompros and personal archives of Konstantin P. von Kaufman; Nikolai I. Veselovskii and Vasilii V. Bartol'd. These are located in the following institutions: the Central State Archive of the Republic of Uzbekistan (TsGA RUz); the Russian State Historical Archive in St. Petersburg (henceforth, RGIA); the St. Petersburg Branch of the Archive of the Russian Academy of Sciences (A RAN (SPb)) and the Archive of the Institute of the History of Material Culture in St. Petersburg (henceforth, A IIMK). While noting the richness of these archival holdings, we should acknowledge their imperial and colonial character. These documents largely reflect the point of view of the imperial and Soviet structures and experts; positions of the indigenous local population are reflected to a very limited extent.

${ }^{13}$ For an excellent analysis of pan-European trends in heritage preservation, see Swensen and Mandler (Eds.). From Plunder to Preservation. The book demonstrates broad similarities, yet also highlights specific differences, of the British, French, and German approaches to preservation. (See, in particular: Pp. 10-12.) 
cultures alone, and it was contrasted with the claimed failure of the colonized to care for "monuments." This failure was regularly cited as one of the justifications of colonial control over non-Europeans, whose "neglect of monuments" was represented as yet another example of their unpreparedness for political independence. ${ }^{14}$ These perceptions were internalized by Russian preservationists. We demonstrate that in Russia, as elsewhere in Europe, "the cult of monuments" became not only an element in the politics of national identity and romantic nostalgia, as Schönle suggests, but also a tool of colonial rule and an area of cultural transfers between the colonized and the colonizers within European empires and of the political competition between empires. ${ }^{15}$

It is also erroneous to think that the interpretation of modernity by the Bolshevik regime was based largely on the radical repudiation of the past. ${ }^{16}$ Particularly radical utopian visions, which included alternative perceptions of time and suggested the complete rejection of earlier cultural heritage, ${ }^{17}$ tended to be criticized by top Bolshevik leaders. ${ }^{18}$ Therefore, after the 1917 revolutions, "the past" in its various forms and manifestations, rather than being repudiated, began to be harnessed in support of the regime, as the new elites strove to take charge of reshaping people's collective memories and identities. The discourse of preservation of the Soviet period highlights tensions at the heart of the Soviet ideological domain between the key assumptions of European modernity, to which the Bolshevik experiment was heir, and the new regime's desire to offer alternatives to Western capitalism,

${ }^{14}$ Astrid Swenson. The Heritage of Empire // A. Swenson and P. Mandler (Eds.). Form Plunder to Preservation. Pp. 3-28.

${ }^{15}$ For an analysis of the European context, see Swenson. Introduction. Pp. 9-15; Nabila Oulebsir. Les usages du patrimoine: monuments, musées et politique coloniale en Algérie. Paris, 2004; Irène Maffi. Pratiques du patrimoine et politiques de la mémoire en Jordanie: entre histoire dynastique et récits communautaires. Lausanne, 2004; Tapati Guha-Thakurta. Monuments, Objects, Histories: Institutions of Art in Colonial and Postcolonial India. New York, 2004; Mercedes Volait. Fous du Caire: excentriques, architectes et amateurs d'art en Égypte (1867-1914). Forcalquier, 2009; Mrinalini Rajagopalan, and Madhuri Desai (Eds.). Colonial Frames, Nationalist Histories. Imperial Legacies, Architecture, and Modernity. Farnham, 2012; Indra Sengupta. Monument Preservation and the Vexing Question of Religious Structures in Colonial India // Swenson and Mandler (Eds.). From Plunder to Preservation. Pp. 171-185.

${ }^{16}$ Schönle. Architecture of Oblivion. P. 223.

${ }^{17}$ Robert C. Williams. The Russian Revolution and the End of Time: 1900-1940 // Jahrbücher für Geschichte Osteuropas. Neue Folge. 1995. Vol. 43. No. 3. Pp. 364-401. ${ }^{18}$ Sheila Fitzpatrick. The Cultural Front. Power and Culture in Revolutionary Russia. Ithaca. 1992. Pp. 91-5. 
nationalism, imperialism, and colonialism, with which the historical experience of tsarist Russia was also associated in the $1920 \mathrm{~s}^{19}$

The tensions were exacerbated by the fact that multiple actors with different agendas were involved in the politics of memory and history. We, therefore, suggest that it is misleading to understand Soviet-era campaigns to preserve historical monuments as a "site of escape from ideologically inflected reality" by a few intellectuals critical of the regime. ${ }^{20}$ Instead, we demonstrate that heritage preservation quickly emerged both as a recognized propaganda tool of the Soviet regime and a site of intense struggles between different actors. These actors included government officials, intellectuals, and experts with different political sympathies and backgrounds, as well as ordinary citizens of different nationalities from the center and from (former) Turkestan. All these actors attempted to "safeguard monuments" at different levels and through different means. Ordinary citizens are often excluded from consideration, yet they had their own views regarding "monuments" which were often different from those held by politicians and academic experts. Overall, the politics of memory and history in Russia, including in the Soviet period, was far more nuanced than a binary opposition of Russia versus the West allows.

The contrast between Russia and the West has historically been used as a framework for self-representation by the Russian elites. This trend further intensified in the Soviet period, with the early Bolshevik regime claiming to be building a new society on an anti-imperial and anticolonial foundation and juxtaposing the new state to both "bourgeois" Europe and tsarist Russia. In both the imperial and Soviet periods, the contrast between Russia and the West usually did not mean associating Russia with the East or Asia, but was used to buttress claims about the specificity or uniqueness of Russian or Soviet identities. The extent to which these discourses and narratives of the Bolshevik regime had any relationship to actual policies and practices has been a subject of wide scholarly debates. Recent scholarship has highlighted the extent to which the persistence post-1917 of the epistemological structures of European modernity ensured that practices of the imperial and

${ }^{19}$ This observation, which relates to the understanding of cultural heritage by representatives of the Soviet regime, further helps us to appreciate multicausal origins of the peculiar form of the Soviet multiethnic state, which have been analyzed in Terry Martin. The Affirmative Action Empire: Nations and Nationalism in the Soviet Union, 1923-1939. Ithaca, 2001, and Francine Hirsch. Empire of Nations: Ethnographic Knowledge and the Making of the Soviet Union. Ithaca, 2005.

${ }^{20}$ Schönle. Architecture of Oblivion. P. 223. 
colonial past continued in the Soviet era. ${ }^{21}$ Yet Adeeb Khalid rightly warns against simplifying the matter, arguing that in terms of "intervention, micromanagement and attitude towards difference" the Soviet regime differed significantly from its tsarist predecessor. ${ }^{22}$

The dynamics of the similarities and differences between the Soviet and tsarist periods are crucial for our analysis and it is particularly important in accounting for the changing roles of indigenous actors in Central Asia across the 1917 divide. Scholars have expressed different views regarding the contributions of different participants in the project of national delimitation (natsional'noe razmezhevanie) in Soviet Central Asia. According to a long-standing, yet rather one-sided position, the creation of the Union republics in Central Asia, which eventually led to the appearance of independent states post-1991, was exclusively a result of Moscow's divide and rule policies. ${ }^{23}$ In contrast, Francine Hirsch suggests the crucial role of Russian (former imperial) scholars in providing the Bolshevik government with the data for carrying out national delimitation that began in 1924 and eventually resulted in the creation of five republics in Central Asia, whose inhabitants began to be understood as forming distinct ethnocultural communities. In Hirsch's account, members of the indigenous Central Asian elites used the opportunities offered by delimitation in order to pursue their own specific goals and increase their power. ${ }^{24}$ Khalid further foregrounds the role of "indigenous" intellectuals-cum-politicians, the Jadids, arguing that the formation of the most powerful Central Asian republic of Uzbekistan in 1924 was "the fulfilment in contingent Soviet conditions of a national project [pursued by Muslim intellectuals] that long predated the Russian

${ }^{21}$ Hirsch. Empire of Nations. 2005; Douglas Northrop. Veiled Empire: Gender and Power in Stalinist Central Asia. Ithaca, 2004; Paula Michaels. Curative Powers: Medicine and Empire in Stalin's Central Asia. Pittsburgh, 2003; Cassandra Cavanaugh. Backwardness and Biology: Medicine and Power in Russian and Soviet Central Asia, 1868-1934. New York, 2001.

${ }^{22}$ Adeeb Khalid. Backwardness and the Quest for Civilization: Early Soviet Central Asia in Comparative Perspective // Slavic Review. 2006. Vol. 65. No. 2. 2006. Pp. 231-251; Idem. The Soviet Union as an Imperial Formation: A View from Central Asia // Ann Laura Stoler, Carole McGranahan, and Peter C. Perdue (Eds.). Imperial Formations. Sante Fe, 2007. Pp. 113-140.

${ }^{23}$ Olivier Roy. La nouvelle Asie centrale ou la fabrication des nations. Paris, 1997; see also Adrienne Lynn Edgar. Review of the books by O. Roy, The new Central Asia: The Creation of Nations (2000), and Paul Georg Geiss, Nationenwerdung in Mittelasien (1995) // Kritika. Exploration in Russian and Eurasian History. 2002. Vol. 3. No. 1. Pp. 182-190.

${ }^{24}$ Hirsch. Empire of Nations. Pp. 160-186. 
revolution..." ${ }^{25}$ In his account, from 1917 onward the Jadids appear as the most important actors in the construction of "national heritage" on behalf of the imagined nation of Muslims of Turkestan through the collection of old manuscripts and folklore as well as preservationist work, and Khalid warns against overstating the role of Russian imperial experts in this endeavor. ${ }^{26}$ Khalid also highlights continuities in Central Asian intellectuals' perceptions of national community and culture across the divides of the 1917 Revolution and the 1924 national delimitation. ${ }^{27}$ In turn, Svetlana Gorshenina, while mentioning that the role of Jadids has been exaggerated in many post-Soviet studies of Central Asia, ${ }^{28}$ also demonstrates that Central Asians, from representatives of the top political leadership to lower-level local administrators, were active participants in the process of national delimitation. ${ }^{29}$

Our analysis suggests that in the case of monument preservation the year 1924 appears as a particularly crucial turning point, constituting a greater shift in the politics of culture in Central Asia than does 1917. At the same time, we point out that political developments in 1924 did not trigger immediate radical transformations. The national delimitation in Central Asia was completed only in 1936; the formation of preservation bodies at the level of newly created Central Asian Union republics began in earnest in 1928. It was only in 1932 that the republican preservation committees began to function independently from the academic centers in Leningrad that had hitherto overseen the maintenance of "historical monuments" in Turkestan. Yet the start of the national delimitation in 1924 gave a major boost to the transformation of monument preservation from being largely an imperial project into predominantly an ethnonational one, with the concurrent appearance of indigenous Central Asian cultural figures as leading preservationists. Such transformation finds parallels in other cases of late colonial and postcolonial conditions, as studies of preservation in other imperial contexts

${ }^{25}$ Adeeb Khalid. Making Uzbekistan: Nation, Empire, and Revolution in the Early USSR. Ithaca, 2015. Pp. 1-2, 15.

${ }^{26}$ Ibid. Making Uzbekistan. Pp. 136, 213, 261.

${ }^{27}$ The continuity argument is particularly strongly foregrounded in Khalid. Making Uzbekistan.

${ }^{28}$ Devin DeWeese. It Was a Dark and Stagnant Night ('til the Jadids Brought the Light): Clichés, Biases, and False Dichotomies in the Intellectual History of Central Asia // Journal of the Economic and Social History of the Orient. 2016. No. 59. Pp. 37-92.

29 Svetlana Gorshenina. Asie centrale. L'invention des frontières et l'héritage russosoviétique. Paris, 2012. Pp. 189-294. See also: Arne Haugen. The Establishment of National Republics in Soviet Central Asia. New York, 2003; Adrienne Lynn Edgar. Tribal Nation: The Making of Soviet Turkmenistan. Princeton, 2004 (particularly chap. 2). 
show. ${ }^{30}$ Yet the context of the Soviet Union as an integrationist multiethnic (mnogonatsional'noe) state inevitably created important specificities. The analysis that follows will be structured chronologically, considering institutions, actors, discourses, and practices in relation to each period. It is necessary to start our account with the period prior to the revolutions of 1917 , as many narratives and practices particularly up to 1924 originated well before the Bolshevik takeover. We end our analysis with the year 1932, which, as we explain, marked the start of yet another stage in the construction of "cultural heritage" in the region.

\section{"Indigenous" Practices and Imperial Approaches to Monument Preservation}

By the time of the Russian imperial conquest of Central Asia in the $1850 \mathrm{~s}-1860 \mathrm{~s}$, there existed local discourses and practices concerning architectural structures of earlier periods. Among the available sources, reflecting local views of the region's "antiquities," are the Qandiya of the eleventh century and the Samariya of the twelfth century AD, the city chronicles of Samarkand, which were revised and updated in the 1840s. They focused almost exclusively on Islamic religious buildings, aiming to create a local religious geography. ${ }^{31}$ At the same time, the native elites of Turkestan, similarly to European imperial elites, appreciated the ideological significance of architecture as a tool for projecting political power. In the eighteenth and nineteenth centuries, local guides who accompanied Russian and European travelers to the region prior to the Russian conquest focused on the buildings and sites that they considered important, thus reflecting local collective memories. Many of those were architectural structures of the specific period, that of the Timurid rule between the fourteenth and the early sixteenth centuries. The city of Samarkand, where particularly striking constructions from this period were in abundance, was represented in the "indigenous" narratives as unmatched anywhere else in the world. In turn, European travelers tended to be particularly interested in those sites about which they had prior knowledge from published travelogues or scholarly publications. Since the eighteenth century, these too emphasized the impor-

\footnotetext{
${ }^{30}$ Swenson. Introduction. P. 7.

${ }^{31}$ Vasilii Viatkin. “Samariia," opisanie drevnostei i musul'manskikh sviatyn' Samarkanda. Abu-Takhir-Khodja. Perevod V. L. Viatkina // Spravochnaia knizhka Samarkandskoi oblasti. 1898 / Turkestanskii sbornik. Vol. 528. Pp. 60-165; Idem. Kandiia Malaia // Spravochnaia knizhka Samarkandskoi oblasti. 1907. Part 7 // Turkestanskii sbornik. Vol. 531. Pp. 1-57.
} 
tance of what was defined as the Timurid architecture. ${ }^{32}$ Thus, when in the 1870s, the Russian colonial administration in Turkestan and academics in the imperial center started to show interest in the preservation activities in the region, the "Islamic architecture" of the Timurids became their main focus. ${ }^{33}$

There were also local approaches to maintaining old buildings and sites, predating the Russian conquest. When conditions permitted, these were restored to a state that allowed them to serve their functional purpose. This often required the considerable reconstruction of original structures, or even their complete destruction and replacement with something newly built. Waqf endowments were used specifically for supporting public buildings of a religious nature. The issues of aesthetics or authenticity were usually of little relevance. Old constructions in a state of ruin were seen as a source of materials for modern buildings. These materials could be attributed a sacred value if they came from a religious building and were used for the construction of a new mosque. ${ }^{34}$

Notably, this treatment of old architectural structures was similar to Russian practices in relation to Orthodox churches. The main purpose of caring for them was to maintain buildings in a state fit for religious services. Therefore, churches were initially excluded from the modern legislation on monument preservation that began to be adopted in the Russian empire in the course of the nineteenth century. ${ }^{35}$ This legislation, influenced by the emerging new approaches to monument preservation in Europe, prioritized architectural structures of the past for their historical value rather than their present-day functional value. As a result, since the 1870 s, rebuilding in accordance with contemporary needs began to be condemned as the destruction of a "monument." 36

${ }^{32}$ Gorshenina. Les faiseurs de patrimoine. Pp. 48-50, 54-55.

${ }^{33}$ See, for instance, a letter from the Minister of Defence V. A. Sukhomlinov to Baron V. F. Frederiks, the Minister of the Imperial Court of 25 July 1912 // RGIA. F. 472. Op. 49. D. 1157. L. 3ob. Also Gorshenina. Samarkand and its Cultural Heritage. Pp. 250-255. ${ }^{34}$ Viatkin. Samariia; Gorshenina. Samarkand and its Cultural Heritage. Pp. 248-250; Eadem. Les faiseurs de patrimoine. Pp. 23-28.

${ }^{35}$ Schönle. Broken History and Crumbling Stones. Pp. 751, 764; Kelly. Socialist Churches. P. 802.

${ }^{36}$ From the time of the French revolution, philosophers of the Enlightenment began to theorize the notion of a "historical monument," as demonstrated, for example, in AubinLouis Millin (1790): Nabila Oulebsir and Austride Swenson. Patrimoine: voyages des mots. Heritage, Erbe, Beni culturali, Turâth, Tigemmi // Patrimoine et Architecture. 2015. Vol. 21-22. Pp. 7-8. Alois Riegl's famous article of 1903 reflects what by then had become a dominant European perception of "cultural heritage". Alois Riegl. Der moderne Denkmalkultus: sein Wesen und seine Entstehung. Wien, Leipzig, 1903. 
In Turkestan, from the start, architectural structures deemed by Russian preservationists to be worthy of attention had been perceived as "historical monuments" in the new European sense. Therefore, their treatment was to be informed not by the principles applied to Orthodox churches, but by those developed for the purpose of modern preservation of sites that were attributed historical value. Therefore, Russian imperial preservationists, similarly to their West European counterparts, began criticizing "indigenous" practices of maintaining old buildings. ${ }^{37}$ The fact that the treatment of "monuments" in European metropoles, let alone across Russia, did not always fit with the ideal of conserving, rather than rebuilding, did not prevent European and Russian preservationists from regarding the "indigenous" treatment of old sites as an example of cultural inferiority ${ }^{38}$ And thus European imperial elites and experts, including in the Russian empire, used the discourse of preservation in order to justify the colonial rule and to represent Europeans as "civilizers" who, as the St. Petersburg orientologist Nikolai I. Veselovskii put it, were safeguarding "from the natives their own treasures." ${ }^{39}$

Veselovskii, who began his explorations in Samarkand in the 1880s, claimed that "the natives (tuzemtsy) are terrible hypocrites. They will not pity any holy place if this can bring profit, and now they have developed a lucrative business in selling antiquities." ${ }^{40}$ In turn, a Turkestani archaeologist and the first official curator of "historical monuments" in Samarkand, Vasilii L. Viatkin, repeated the narratives of earlier European travelers to Central Asia, stating in 1906 that monuments' "repairs (remont) [undertaken by the "natives"] did not lead to the strengthening (ukreplenie) of the architectural structures but only deformed them in an ugly way (bezobrazili)." ${ }^{\text {"4l }}$ Particular attacks were heaped on the post-Timurid Turkic inhabitants of Central Asia, who were often described as being of "a different race" from the Timurids and as being neither able to produce anything comparable to the heritage of the Timurid period nor properly to care for the treasures they inherited. ${ }^{42}$

${ }^{37}$ Yannis Hamilakis. Indigenous Archaeologies in Ottoman Greece // Z. Bahrani, Z. Celik, and E. Eldem (Eds.). Scramble for the Past: The Story of Archaeology in the Ottoman Empire 1733-1914. Istanbul, 2011. Pp. 52-53.

${ }^{38}$ Swenson. Introduction. P. 25.

${ }^{39}$ A IIMK. F. 18. D. 12. L. 160ob.

${ }^{40}$ Dokladnye zapiski N. I. Veselovskogo // A IIMK. F. 18. D. 11. L. 8.

${ }^{41}$ Otchet smotritelia nad pamiatnikami stariny v Samarkande, aprel' 1906 // TsGA RUz. F. R-1591. Op. 2. D. 25. L. 36.

${ }^{42}$ A RAN. F. 68. Op. 1. D. 69. L. 2. Such statements were already made in the eighteenth century. See, for example, Iakov V. Khanykov. Poezdka iz Orska v Khivu i obratno sovershennaia v 1740-1741 godakh Gladyshevym i Muravinym, izdana s priobshcheniem 88 
However, developments on the ground often challenged any attempt to draw a stark contrast between "indigenous" practices and those of Russian or European actors. The Russian critique downplayed the fact that the rise in sales in antiquities in Central Asia was due to the emergence of bourgeoning markets for old artifacts in Western Europe and Russia. ${ }^{43}$ Furthermore, many of the preservationist projects undertaken by the Russian colonial authorities in this period similarly failed to fit with the ideal European standards of preservation.

At first glance, preservation projects that began under the first governorgeneral of Turkestan, Konstantin von Kaufman, in the 1870s did reflect the new understanding of particular architectural structures as "historical monuments." In Samarkand, the mausoleum of Timur, Gur-Imir, and the Bibi-Khanym mosque, as well as the Registan, saw their status as "monuments" visually emphasized during the restoration work carried out by the Russian imperial authorities. The buildings and the site were surrounded with latticed railings and roads leading to them were laid. Squares were built in front of Gur-Imir and Bibi-Khanym. Trading markets and a horse stable were also removed, thus narrowing the polyvalent meanings of these multifunctional sites and integrating them as "monuments" into the urban landscape. Yet Russian military men, who worked on these historical sites, did not hesitate to resort to rebuilding in order to strengthen old constructions, using modern European bricks in the process. The latter practice was, in fact, criticized by the local population. Thus the criticism of ignoring the issue of authenticity and historical value could equally be made in relation to these imperial preservation activities. ${ }^{44}$

Despite the existence by the early twentieth century of a range of organizations that were involved in preservation in Central Asia, such as the Turkestan Society of the Lovers of Archaeology and the Turkestani Branch of the Geographical Society, as well as the St. Petersburg-based Imperial Archaeological Commission and the Russian Committee for the Study of Central and Eastern Asia, limited progress was made not only in the area of conservation but even in the basic registering of the existing monuments. ${ }^{45}$

sovremennoi karty millerova puti ot Orska do Zjungorskikh vladenii i obratno Ia. V. Khanykovym. St. Peterburg, 1851 // Turkestanskii sbornik. Vol. 343. Pp. 43b, 47b.

${ }^{43}$ Svetlana Gorshenina. Private Collections of Russian Turkestan in the 2nd Half of the 19th and Early 20th Century. Berlin, 2004.

${ }^{44}$ Gorshenina. Samarkand and its Cultural Heritage. Pp. 254-255.

${ }^{45}$ TsGA RUz. F. I-47. Op. 15. L. 273, 4; F. I-907. Op. 1. D. 99. L. 43-43ob; F. I-907. Op. 1. D. 97. L. $48-48$ ob. 
The most pressing problem was funding. Attempts to obtain it from the imperial government in St. Petersburg or the local military administration in Turkestan were often unsuccessful. Any allocation was considerably smaller than the preservationists lobbied for. ${ }^{46}$

In order to convince the authorities as to why often scarce resources should have been spent on preserving monuments in Central Asia, the latter were reimagined from representing the past of the Asian Other into symbols of the Russian imperial Self. Here again the transimperial discourse of preservation was at work. As in the late nineteenth century the states' ability to preserve old monuments began to be seen in Europe as a measure of their civilizational development, Russian preservationists could argue that any neglect of monuments would encourage Western perceptions of Russia as a backward society, unable to properly care for the treasures it inherited. ${ }^{47}$ The preservation of monuments was, thereby, included in Russia's "civilizational mission" in Central Asia, which symbolically buttressed the status of the Russian empire as one of leading European powers. The preservation of monuments in Turkestan was claimed to be particularly important for two reasons. The first was that in the official imperial discourse the new Russian rulers of Central Asia were represented as heirs to Tamerlane, the founder of the Timurid dynasty. ${ }^{48}$ The second reason was formulated by Russian orientologists who stressed the exceptional cultural significance of Turkestan's monuments. ${ }^{49}$

As Schönle demonstrated, Russian intellectuals perceived European Russia as lacking in historical monuments that could match those found in Western Europe..$^{50}$ The narrative articulated by Russia's leading expert on Central Asia Vasilii V. Bartol'd and other orientologists suggested that Central Asia possessed the treasures that would allow Russia to place itself on the same level as, or even higher than, the West in terms of the monuments it could claim as part of its cultural heritage. "In Central Asia," Bartold argued, "Russia incorporated a region with [truly] ancient culture, compared to what we find in European Russia and Siberia. Apart from some parts of

\footnotetext{
${ }^{46}$ See, for example, RGIA. F. 472. Op. 49. D. 1157. L. 10, 12, 15, 17.

${ }^{47}$ RGIA. F. 472. Op. 49. D. 1157. L. 1, 16-16ob.

${ }^{48}$ Gorshenina. Les faiseurs de patrimoine. Pp. 124-126; Eadem. Samarkand and its Cultural Heritage. Pp. 257-258.

${ }^{49}$ N. Veselovskii. Mecheti Samarkanda. Vol. 1. Gur-Emir. St Petersburg, 1905; Vasilii V. Bartol'd. Zadachi russkogo vostokovedeniia v Turkestane // Bartol'd. Sochineniia. Vol. IX. Moscow, 1974. P. 529.

${ }^{50}$ Schönle. Broken History and Crumbling Stones. Pp. 758-759. 
Transcaucasia, there are no societies with a more ancient culture within Russia than Turkestan." ${ }^{1}$

Also with specific reference to Turkestan (as well as the Caucasus), Bartol'd's colleague Veselovskii asserted that in terms of "quantity, richness, and variety of antiquities Russia without exaggeration ranks the first in the world." 52 Such claims refashioned Turkestan from a "backward colony" and a drag on Russian state resources, which was common among officials in the imperial capital, into the center of the empire's cultural treasures.

From the early times of Russian rule the fact that the monuments in question were connected to Islam was seen as a political problem by some representatives of the imperial authorities. According to this position, given that "monuments in Turkestan are also holy places for local Muslims, the Russian government should not be taking care of them," as it would only encourage the religious fanaticism of the local population. ${ }^{53}$ Different arguments were used by those favoring preservation to rebut such concerns. One was the "neutralization" of the religious nature of the monuments by representing them as having historical value of particular importance only for European scholarship and culture. In this context the fact that the aim was "not to restore the monuments to their entire former glory," but just to conserve what had survived, was emphasized. ${ }^{54}$

The second argument in defense of preservation was the idea articulated at the turn of the twentieth century by Russian imperial orientologists about the integrationist potential of monument preservation for the benefit of the entire empire. Bartol'd propagated the integrationist potential of monument preservations on the pages of the journal Mir Islama, where he rejected as unfounded the view that the preservation of monuments of Islamic architecture would only "strengthen local separateness at the expense of the spiritual merger (dukhovnomu sliianiiu)" with the Russians. In his view the effect would be just the opposite. ${ }^{55}$ Here again there were parallels with other imperial contexts. This was the period when various projects favoring

${ }^{51}$ V. V. Bartol'd. Stat'ia o sostoianii Bukharskogo khanstva i voobshche Turkestana // A RAN, SPb. F. 68. Op. 1. D. 448. L. 1.

${ }^{52}$ Quoted in Pravilova. Contested Ruins. P. 89.

${ }^{53}$ RGIA. F. 472. Op. 49. D. 1157. L. 19ob. This position was, for instance, typical for one of the last tsarist governors-general of Turkestan, Aleksandr Samsomov. See M. E. Masson. Tri epizoda, sviazannye s samarkandskimi pamiatnikami stariny. Tashkent, 1972. P. 20.

${ }^{54}$ RGIA. F. 472. Op. 49. D. 1157. L. 19 ob.

${ }^{55}$ V. V. Bartol'd. Ot redaktsii // Mir Islama. No. 1. 1912, quoted from V. V. Bartol'd. Sochineniia. Vol. 6. Moscow, 1966. P. 375. 
closer integration of colonies with metropoles were articulated in European empires. In Britain, as in Russia, preservation was evoked as a tool for achieving imperial cohesion. ${ }^{56}$ The indigenous population of the colonies was expected to feel gratitude toward imperial powers for protecting local heritage, thereby developing stronger imperial loyalties.

In this context, the question of who owned the past started to require a more careful consideration. Yet again contradictory answers were given. On the one hand, since the late nineteenth century, imperial preservationists tended to argue that the Russian imperial state should be regarded as the main owner of the historical heritage on its territory. As Veselovskii argued, great monuments "should be considered the property of the state" (dostoianiem gosudarstva) and in relation to them "private interests should give way to state ones." ${ }^{57}$ References were also made to the importance of monuments in Europe/Russia's colonial domains for the international (i.e., European) scientific community. ${ }^{58}$ At the same time, particularly from the second decade of the twentieth century, an argument increasingly started to be made that the indigenous population of Central Asia also had a legitimate claim on these treasures, and the cooperation between the two sides might achieve better results in preservation. Therefore, in 1910, the Imperial Defense Ministry proposed to the governor-general of Turkestan the establishment of a special commission for the preservation of the monuments of antiquity in the region that would include "influential representatives of the native population," thereby "helping to raise voluntary contributions from that population" as a source of funding for preservation. ${ }^{59}$ Turkestan's leading preservationist, Viatkin, in turn, argued that "Muslims are very responsive when it comes to their holy places" and therefore would donate generously for preservation activities, if a specific fund were to be set up in Turkestan. ${ }^{60}$ Ultimately, such a fund or commission was never established before the 1917 Revolution, and preservationist activities remained dominated by imperial officials, St. Petersburg orientologists and Russians like Viatkin who permanently relocated to Turkestan after the conquest.

Central Asian Muslims reacted differently to Russian imperial preservationist activities. There are many examples of the involvement of Central Asians in these activities alongside Russians. These include local collec-

\footnotetext{
${ }^{56}$ Swenson. Introduction. Pp. 9-10.

${ }^{57}$ A IIMR. F. 18. D. 11. L. 1.

${ }^{58}$ A IIMK. F. 18. D. 11. L. 9ob.; F. 18. Op.1. D. 32. L. 6-7.

${ }^{59}$ RGIA. F. 472. Op. 40. D. 1157. L. 160 .

${ }^{60}$ TsGA RUz. F. R-1591. Op. 2. D. 25. L. 36.

92
} 
tors of antiquities who shared their findings with Russian orientologists and museums in the imperial capitals, ${ }^{61}$ local craftsmen who took part in the preservation projects, ${ }^{62}$ and local Muslim members of the Turkestan Circle of Lovers of Archaeology such as Akram Pavlon Askarov and Mirza Abdulla Bukhari. ${ }^{63}$ Scholarly articles appeared in academic journals about ancient monuments by figures such as Abubakir Divaev, a Bashkir from Turkestan who was closely involved in archaeological work, as well as Kazakh scholars Chokan Valikhanov, Nogaibai Dzetbysbaev, and Sherali Lapin. ${ }^{64}$ Their publications reflected the acceptance by these authors of the European concept of a "historical monument."

An overt rejection of Russian initiatives was also evident, however. Since the last years of the nineteenth century, Muslim communities in Turkestan often protested against the involvement of Russian engineers in the preservation and restoration of buildings of religious significance on the grounds that Russian technical norms did not fit with local practices and that the very presence of non-Muslims in the holy places was ungodly ${ }^{65}$ Local communities at times also agreed to donate funding for preservation activities only if the work would be conducted by "native" craftsmen. ${ }^{66}$

Overall, by the time of the revolution, Russian imperial discourses and practices surrounding monument preservation in Central Asia were shaped by the European transnational and transimperial cultural context. Their ideological underpinnings often clashed with "indigenous" perceptions, yet actual practices were not nearly as contrasting as Russian imperial

${ }^{61}$ Gorshenina. The Private Collections. Pp. 17-32.

${ }^{62}$ TsGA RUz. F. I-1. Op. 20. D. 2892. L. 1, on the participation of such craftsmen in the first restoration works at the Gur-Emir mausoleum in Samarkand.

${ }^{63}$ G. N. Chabrov. Uzbeki-arkheologi dorevoliutsionnogo Uzbekistana // Zvezda Vostoka. 1957. No. 1. Pp. 144-146.

${ }^{64}$ Zapiski Vostochnogo otdeleniia Imperatorskogo Russkogo geograficheskogo obshchestva. St Petersburg, 1903. Vol. XV. Part. 1. Pp. viii-ix; 1901. Vol. XIII. Part. 1-4. Pp. 39-40, 113; S. K. Lapin. Perevod nadpisei na istoricheskikh pamiatnikakh g. Samarkanda // Spravochnaia knizhka Samarkandskoi oblasti. 1896. Vol. 4 // Turkestanskii Sbornik. Vol. 532. Pp. 51-71, and Vol. 627. Pp. 784-804; S. Lapin. Shahi-Zinda i ego namogil'nyi pamiatnik // Spravochnaia knizhka Samarkandskoi oblasti. 1896// Turkestanskii Sbornik. Vol. 532. Pp. 85-95; N. Dzetbysbaev. Slovo “mug”, kurgany i kamennaia baba// Protokoly Turkesrtanskogo kruzhka liubitelei arkheologii. 1901. Vol. V. Pp. 28-34.

${ }^{65}$ K. K. Palen. Otchet po revizii Turkestanskogo kraia, proizvedennoi po vysochaishemu poveleniiu Senatorom Gofmeisterom Grafom K. K. Palenom. Kraevoe upravlenie. St. Petersburg, 1910. Pp. 62-63; B. Ia. Staviskii. Problemy sokhraneniia pamiatnikov kul'tury i iskusstva v sovetskikh respublikakh Srednei Azii (1917-1941). Vol. 1. Moscow, 1989. P. 6. ${ }^{66}$ Palen. Otchet po revizii Turkestanskogo kraia. Pp. 62-63. 
preservationists tended to claim. What were called monuments of Islamic architecture were imagined by Russian imperial administrators and experts as places of memory of the entire Russian empire, the need for whose preservation justified Russian colonial rule. In the Russian imperial politics of history and memory Turkestani monuments were usually deprived of their religious importance and transformed into the objects of scientific exploration. At the same time, the state's increasing interest in imperial integration put on the agenda the issue of the relationship to the same historical sites of the "indigenous" population, whose representatives both shared and opposed Russian approaches to preservation.

\section{From the Revolution to the National Delimitation: 1917-1924}

In the immediate aftermath of the revolution, Turkestan was cut off from European Russia, while short-lived political entities emerged in the region. Yet by the elites in Petrograd and Moscow Turkestan continued to be perceived as part of the Russia-dominated domain. Thus, from 1918 onward, the issue of monument preservation in Turkestan began to be discussed with revived intensity in academic institutions, such as the Russian Academy of Sciences and the Academy of the History of Material Culture (AIMK) that replaced the Imperial Archaeological Commission in Petrograd, as well as in the new governmental body, the Department for the Affairs of Museums and Monument Preservation (Glavmusei) of the RSFSR Commissariat of Popular Enlightenment (Narkompros) in Moscow. ${ }^{67}$ Several small-scale preservation bodies were also set up in Turkestan in 1918 and 1919, thus ensuring an uninterrupted link with the prerevolutionary period in terms of personnel, ideological assumptions, and practices. ${ }^{68}$

In response to the lobbying of various actors who had been involved in preservation under the old regime, in November 1918, the RSFSR Narkom-

${ }^{67}$ I. A. Sorokina. Organizatsiia rossiiskoi polevoi arkheologii v pervye gody posle dvukh revoliutsii (1917-1920 gg.) // Rossiiskii arkheologicheskii ezhegodnik. 2014. No. 4. Pp. 499-514.

${ }^{68}$ In 1918 these were a commission headed by Viatkin in Samarkand to preserve a minaret of the Ulugh Beg madrasah and another commission for the preservation of Samarkand monuments headed by the Armenian painter, Oganes K. Tatevosyan. See: M. E. Masson. Padaiushchii minaret (severo-vostochnyi minaret Samarkandskogo medrese Ulugbeka). Iz vospominanii uchastnika podderzhaniia i vypremleniia "padaiushchego minareta". 1918-1922. Tashkent, 1968. Pp. 5-10, 14; Gorshenina. Turkomstaris. P. 53. In 1919, a separate Commission for the Study of the Ancient Culture of Turkestan was established by the Narkompros of the Turkestan Republic under the leadership of S. Abusattarov. See TsGA RUz. F. R-3. Op. 1. D. 204. L. 1. 
pros issued a resolution stipulating that "not a single architectural structure or monument that is more than 70 years old or that is of historical value can be repaired, rebuilt, or used for any purpose without the permission of the Archaeological Department." 69 The resolution claimed that "the failure to obey this will be punished according to the strict laws of revolutionary times." ${ }^{\prime 70}$ It goes without saying that the resolution was often ignored, for example, as in Bukhara when it was captured by the Red Army in 1920 . There, not only were some "monuments" damaged by bombing, but old mosques and madrasah, including Khoja-Gaukusan, were rebuilt by the revolutionary authorities to be turned into a hotel and a theater; the emir's palaces were taken over by the army for its own use. ${ }^{71}$

Still, at least discursively, with the establishment of Soviet rule in Turkestan in 1920, rather than being pushed to the margins of politics, the maintenance of old Islamic monuments was represented as being of utmost importance in soliciting support for the Soviet regime in the region and spreading revolution abroad. In the words of one Soviet government appointee, Dmitrii I. Nechkin, who was sent to Turkestan in 1920 to deal with cultural matters, monument preservation reflected "all the nuances of the Eastern policies" of the Soviet state and "attracted attention of the masses to a much greater extent than any other means of propaganda." 72 In the center and locally, champions of the preservation agenda combined the prerevolutionary narratives about the state's attitude to monuments as a measure of its civilizational development and about the "exceptional significance" of Central Asian cultural heritage, ${ }^{73}$ with the new imperative of the Soviet regime to win over the sympathies and loyalties of the local indigenous elites and the population at large. In a place such as Turkestan, where support for the Soviet regime was extremely weak, a temporary accommodation of Islam was an inevitable, pragmatic step. ${ }^{74}$ The rhetoric

${ }^{69}$ This is likely to be a reference to the Archaeological subdvision (podotdel) of the AllRussian Department for the Affairs of Museums and the Preservation of Monuments, which was set up by the RSFSR Narkompros in 1918. See, Sorokina. Organizatsiia rossiiskoi polevoi arkheologii. Pp. 504-506.

${ }^{70}$ A IIMK. F. 67. Op. 1. D. 8. L. 7.

${ }^{71}$ TsGA RUz. F. R-394. Op. 1. D. 183. L. 97; D. 93. L. 2; and D. 186. L. 2.

${ }^{72}$ TsGA RUz. F. R-394. Op. 1. D. 28. L. 331.

${ }^{73}$ A IIMK. F. 67. Op. 1. D. 27. L. 17.

${ }^{74}$ This combination of narratives finds a parallel in the approaches to preservation developed under the first Russian governor-general of Turkestan, Kaufmann. However, his name was, of course, not evoked by Nechkin. Gorshenina. Les faiseurs de patrimoine. Pp. 57-129. 
and strategy of the revolutionary mass mobilization made the involvement of the local Muslim population in preservation activities, already started under the tsarist government, a more topical issue. The implementation proved to be a controversial matter, however. The revolutionary situation also resulted in years of uncertainty regarding the role of the center and the localities in decision making, which created further tensions around preservation issues.

In the context of the devastating impact of the Great War, the Revolution, and the Civil War, the frequency of public claims about the need to treat preservation as a priority of the new regime and the intensity of the legislative activities around the issue in the first postrevolutionary years are particularly striking. Between 1920 and 1923, Turkestan's Council of People's Commissars and Narkompros emerged as the main authorities, issuing resolutions about the protection of local monuments from nature and "evil human activities" (zloi chelovecheskoi voli), as well as about the need to publicize the importance of preservation among the masses through "lectures, talks, and guided tours" and "to regulate the export of cultural artifacts from Turkestan." 75

The new governing bodies in Turkestan and, particularly its Narkompros, attracted into their ranks members of the indigenous cultural elite, the Muslim reformer Jadids. Prior to the revolution they began to think in national terms and to appreciate the importance of studying "cultural heritage" in forging new identities among the region's population. ${ }^{76}$ Yet in the first postrevolutionary years, the preservation bodies continued to be dominated by Russians/Europeans and particularly by those who had been involved in preservation under the tsarist regime. These included the above-mentioned Viatkin as well as an archaeologist of the French origin, Iosif Kastan'e (Joseph Castagné), and a former colonial administrator and orientalist Aleksandr Semenov, with Bartol'd continuing in his role as main academic adviser.

Between 1920 and 1924, two bodies emerged as particularly significant in the area of preservation. One was Turkomstaris (the Turkestan Committee for the Affairs of Museums and the Preservation of Monuments of

${ }^{75}$ A RAN (SPb). F. 68. Op. 1. D. 443. L. 27; TsGA RUz. F. R-394. Op. 1. D. 12. L. 122; A IIMK. F. 67. Op. 1. D. 8. L. 16, 18.

${ }^{76}$ See, for example, Adeeb Khalid. Nationalizing the Revolution in Central Asia: The Transformation of Jadidism, 1917-1920 // Ronald G. Suny and Terry Martin (Eds.). A State of Nations: Empire and Nation-Making in the Age of Lenin and Stalin. Oxford, 2001. Pp. 145-162. 
Antiquity, Art, and Nature), ${ }^{77}$ which was assigned overall responsibility for the monuments on the territory of Soviet Central Asia, and another was the Samarkand Commission, which focused on that particular city. Whereas Viatkin continued to act as the most prominent preservationist in Samarkand, Nechkin was appointed by the RSFSR Narkompros to head Turkomstaris. As we will see, to a significant extent, Nechkin, a person with a workingclass background and a member of the parties of Socialist Revolutionaries (SR) and Social Democrats (RSDRP) between 1903 and 1917, internalized prerevolutionary narratives about preservation. ${ }^{78}$

The contribution of former imperial experts was actively sought by the new revolutionary authorities in Central Asia. Thus, in September 1920, following the establishment of the Soviet government in Bukhara, on the initiative of the Commission for the Affairs of Turkestan at the All-Russian Central Executive Committee (VTsIK) and the invitation of the nazir (commissar) of enlightenment in the Bukhara republic, Jadid Fayzulla Xo'jayev, Viatkin, and several former imperial orientologists, including Bartol'd and Aleksandr Schmidt, went to Bukhara to survey the nationalized property of the emir and to offer suggestions regarding its preservation. ${ }^{79}$ In the next three years, according to Nechkin, Turkomstaris several times surveyed Bukhara monuments, with "the Bukhara government demonstrating consistent sympathy" for such initiatives. ${ }^{80}$

Until 1924, the direct involvement of representatives of the indigenous population in the activities of the established preservation bodies was limited, however ${ }^{81}$ Periodically, Turkomstaris and the Samarkand Commission were

77 Turkomstaris, subordinated to the Narkompros of Turkestan, was founded in May 1921. See, TsGA RUz. F. R-1. Op. 1. D. 122. L. 5. In 1924, the committee was renamed as Sredazkomstaris (i.e., the Central Asian Committee).

${ }^{78}$ See M. S. Isakova. D. I. Nechkin i stanovlenie gosudarstvennoi arkhivnoi sluzhby Uzbekistana (1919-1923) // Otechestvennye arkhivy. 2009. No. 6. Pp. 8-9.

${ }^{79}$ A IIMK. F. 67. Op. 1. D. 27. L. 17. The advisers suggested that particular attention was to be paid to the cataloging of old manuscripts still remaining in the city following the damage inflicted on its artifacts and monuments during the invasion. This task was carried out by the Bukhara Jadid, Musa Saidjonov. See Khalid. Making Uzbekistan. P. 136. Khalid describes the production of Saidjonov's catalog as a manifestation of "new historical sensibilities" among representatives of the Central Asian intellectual elites. On Saidjonov, see Svetlana Gorshenina. Musa Saidzhanov - istorik, arkheolog, iskusstvoved // Obschestvennye nauki v Uzbekistane. 1995. No. 1-3. Pp. 296-329.

${ }^{80}$ A IIMK. F. 67. Op. 1. D. 27. L. 17.

${ }^{81}$ Khalid (Making Uzbekistan. P. 136) refers to the creation in July 1921 by the Bukhara Ministry of Education of the History and Archaeology Society with the aim of studying historical monuments in Bukhara, of which Fitrat and Sharifjon Makhdum were members. 
criticized by the governments in Turkestan and Moscow for having only "Russian comrades as members." ${ }^{82}$ In turn, in 1922, the RSFSR Sovnarkom directly linked the funding it was willing to allocate to Turkomstaris and the Samarkand Commission to the participation of the local Muslim population in their initiatives. ${ }^{83}$ Yet this appeared to be rather difficult to achieve.

In their attempts to defend Turkestan's preservation bodies from criticism of their domination by Russians, yet to emphasize the importance of their mission, leading preservationists used conflicting narratives. The greatest inconsistency was in the representation of the attitudes of ordinary Central Asians to their historical heritage and in the discussion of the issue of the ownership of the past. Particularly when lobbying Moscow for funding, Nechkin and other preservationists argued that local Muslims "have a particularly sensitive and attentive attitude toward Islamic architecture," hence the need to ensure that the Soviet power demonstrated its commitment to preservation. Such a commitment, Nechkin argued, could help in overcoming "the cautious attitude of Muslims to the Soviet regime in general and its representatives in the localities." ${ }^{\circledR 4}$ Even Muslims abroad would be "positively influenced" if the Soviet authorities demonstrated that they "cared for the monuments of Turkestan," which, in the words of Nechkin, "are regarded as a kind of Mecca" by all "the Muslims of the East." ${ }^{85}$ In this context, Turkomstaris stressed the need to approach any work on the monuments "within the limits that religious feelings of Muslims allow." This call for sensitivity represented a striking contrast to the disregard of "religious feelings" of Orthodox Christian believers in Russia at that time, especially in 1918-1920 during the campaign against the so-called holy relics. ${ }^{87}$ Significantly, Nechkin's line of argument was accepted by some leading Bolsheviks, particularly the people's commissar for foreign affairs, Georgii Chicherin, who was an active supporter of funding for preservation projects in Central Asia on the grounds that this attitude "would assist the Bolshevik regime with the task of spreading revolution in the 'Muslim East'." 88

No information on the creation and activities of this commission has been found in the archival documents available to these authors.

${ }^{82}$ Gorshenina. Turkomstaris. P. 58.

${ }^{83}$ TsGA RUz. F. R-394. Op. 1. D. 28. L. 442.

${ }^{84}$ TsGA RUz. F. R-34. Op. 1. D. 2104. L. 331.

${ }^{85}$ TsGA RUz. F. R-394. Op. 1. D. 28. L. 333.

${ }^{86}$ TsGA RUz. F. R-394. Op. 1. D. 3. L. 39. See also, F. R-394. Op. 1. D. 28. L. 333.

${ }^{87}$ Steve Smith. Bones of Contention: Bolsheviks and the Exposure of Saints' Relics, 1918-30 // Past and Present. 2009. Vol. 204. No. 1. Pp. 155-194.

${ }^{88}$ TsGA RUz. F. R-394. Op. 1. D. 213. L. 147.

98 
On other occasions, however, the opposite narrative, dating back to the pronouncements of European and Russian travelers to the region in the eighteenth-early twentieth centuries, ${ }^{89}$ was adopted by preservationists who depicted the native population of Turkestan as exhibiting a "total lack of interest" in their cultural heritage.${ }^{90}$ The main complaint of Turkomstaris and the Samarkand Commission was that local people used as building material bricks and stones from historical monuments that were in a state of ruin. This was represented as examples of "backwardness and [cultural] stagnation" of the region. ${ }^{91}$ In fact, during the Civil War, as well as later during industrialization, the same practices of using old architectural structures, particularly churches, as a source of building material, were recorded in European Russia. ${ }^{92}$ Yet Central Asian preservationists never acknowledged this parallel. Instead the history of Central Asia was represented similarly to what was argued by Russian experts in the prerevolutionary period. The period of the Timurid rule as the golden age of Central Asia was contrasted with that of the subsequent Turkic conquerors of the region who, it was argued, allowed decay and stagnation to occur. ${ }^{93}$

Before the revolution people such as Bartol'd castigated the tsarist government for failing to put enough effort into monument preservation. ${ }^{94}$ The same criticism was repeated post-1917, as tsarist rule was now contrasted to the Soviet regime, which was represented as finally acting in the interest of the local population in its special care for monuments. ${ }^{95}$ This care was often described, however, through paternalistic claims typical of European colonial powers. In this representation, the new regime's preservation activities appeared as a tool in its broader campaign against "the centuries-long fanaticism of the natives." And thus, the British archaeological department in colonial India in the 1920s continued to be cited as a model from which Turkomstaris could learn. ${ }^{96}$

${ }^{89}$ Gorshenina. Samarkand and its Cultural Heritage. Pp. 251-2.

${ }^{90}$ TsGA RUz. F. R-394. Op. 1. D. 3. L. 262.

${ }^{91}$ TsGA RUz. F. R-394. Op. 1. D. 3. L. 262.

${ }^{92}$ Kelly. Socialist Churches. P. 821.

${ }^{93}$ TsGA RUz. F. R-394. Op. 1. D. 3. L. 262.

${ }^{94}$ At the same time, Bartol'd always made an exception in relation to the first Russian governor-general, Kaufmann, arguing that the latter "did more for safeguarding monuments [in Turkestan] than the British had done in India." Zapiski Vostochnogo otdeleniya Imperatorskogo Russkogo arheologicheskogo obshestva. 1900. Vol. XII. No. 1, 4. P. 138; V. V. Bartol'd. Sostoianie i zadachi izucheniia istorii Turkestana// Bartol'd. Sochineniia. Vol. 9. Moscow, 1977. P. 533.

95 TsGA RUz. F. R-394. Op. 1. D. 3. L. 262.

96 TsGA RUz. F. R-394. Op. 1. D. 143. L. 89. 
These inconsistent narratives were articulated amid actual conflicts between people and policies. Overall, the leadership of the preservation bodies agreed with the central and local governments that the membership of Central Asians in these bodies was essential. The matter was regularly discussed at meetings of Turkomstaris and the Samarkand Commission, and suggestions were expressed "to co-opt two or three representatives of the Muslim Spiritual Administration or other notable figures, who enjoyed the trust of local Muslims. ${ }^{.97}$ Problems, however, regularly arose in carrying out this plan. Turkomstaris and the Samarkand Commission's reports include complaints that either no one volunteered for membership in the first place or that selected individuals, including a representative of the Muslim Spiritual Administration and other religious figures, failed to show up at meetings. ${ }^{98}$ Predictably, the leadership of Turkomstaris and the commission claimed that the reason was the lack of sufficient interest in preservation on the part of the indigenous population. Yet, in 1922 when a practicing Muslim did become an active member of the Samarkand Commission, both its leadership and Nechkin were also dissatisfied, thus suggesting a different explanation for this domination of the main preservation bodies by "Russian comrades."

This active participant was Abdul-Koium Kurbiev (Kurbi), ${ }^{99}$ who did not hesitate to come up with initiatives and to offer his frank assessment of the commission's work. Consequently, in letters and reports by leading members of the commission and by Nechkin, Kurbi appears to be untrustworthy troublemaker. Eventually, Kurbi was removed from the commission, following Nechkin's appeal to the Turkestan Central Executive Committee in December 1922. Nechkin accused Kurbi of attempting to "discredit in the eyes of local Muslims the usefulness and scientific nature of the activities of the Samarkand Commission." 100 Similar accusations were repeated at the commission's own meetings. ${ }^{101}$ Conversely, letters written by Kurbi himself suggest that he lobbied for the use of what he called "traditional methods" of local craftsmen during repairs, such as the use of old Central-Asian bricks and plant-based paints, rather than contemporary European ones. He also insisted that certain work carried out by the commission was offensive to the religious feelings of the local population. The main controversy was

${ }^{97}$ Gorshenina. Turkomstaris. Pp. 58-60.

${ }_{98}^{98}$ TsGA RUz. F. R-1. Op. 1. D. 28. L. 19, 364, 392, 424, 429.

${ }^{99}$ The authors were unable to reconstruct Kurbi's background and life from the available archival documents.

${ }^{100}$ TsGA RUz. F. R-394. Op. 1. D. 28. L. 412.

${ }^{101}$ TsGA RUz. F. R-394. Op. 1. D. 28. L. 429-431, 440.

100 
around the Ulugh Beg madrasah's falling minaret, with Kurbi, on the one hand, and the rest of the commission, on the other, proposing different ways of straightening it. ${ }^{102}$

The Samarkand Commission's leadership and Nechkin represented the conflict as primarily a clash of values attributed to the "monuments." They argued that their approach foregrounded the age and historical values of the monument, which were of particular "importance for scholarship" (znachenie dlia nauki). Kurbi, in contrast, seemed to have been concerned with these monuments' value as a functional site of particular significance for practicing Muslims. In reality, practical plans of both sides for maintaining the site disregarded the issue of "authenticity," which was emphasized in the European scientific discourse of preservation. In the absence of other means, the commission's decision was to strengthen the Ulugh Beg minaret by tying it to a large anchor placed on the ground. Kurbi suggested using the "indigenous" method of building an arch to prop up the falling construction. ${ }^{103}$

In fact, as is often the case with conflicts between individuals within institutional structures, disagreements between Kurbi and the leadership of the Turkestan preservation bodies were likely to have been linked to the issue of personal power. The available documentation suggests that Nechkin was particularly angered by Kurbi's attempts to directly contact Glavmusei of the RSFSR Narkompros about preservation issues in Samarkand. This exemplified an unacceptable "separatist" tendency, Nechkin insisted. According to him, only Turkomstaris - that is, Nechkin himself - had the right to directly communicate with Moscow. ${ }^{104}$ But, in fact, the issue of hierarchy and subordination was far from clearly determined and various sides accused each other either of excessive control or "separatism." In 1923, for example, the Samarkand Commission was unhappy that the Waqf Administration in the city "carried out repair and restoration (remontno-restavratsionnye) work on the Ulugh Beg madrasah independently," whereas they were supposed "to act under the supervision of the commission." 105 According to the commission, the administration's failure to consult caused technical mistakes to be made. At the same time, the commission was also unhappy about what its leadership regarded as excessive control by Turkomstaris and its chairman Nechkin, which tended to make the Samarkand Commission "powerless"

102 Ibid. L. 430.

103 TsGA RUz. F. R-394. Op. 1. D. 28. L. 430-431.

104 TsGA RUz. F. R-394. Op. 1. D. 28. L. 346.

${ }^{105}$ A IIMK. F. 67. Op. 1. D. 27. L. 6ob. 
(bespravnaya). ${ }^{106}$ Nechkin, in turn, complained about what he regarded as the excessive authority of the Waqf Administration over funding, ${ }^{107}$ as well as about the tendency of the Academy of the History of Material Culture in Petrograd to act as if final decisions were entirely its own prerogative. ${ }^{108}$ His accusations of separatism were leveled not only against Kurbi but also against the head of the Samarkand Commission, who was a Russian.

Conflicts around administrative control and subordination, in part, reflected the actors" differing positions on the broader question of the "ownership" of historical monuments. (This was, of course, only the symbolic ownership, given that the Bolshevik government made real estate the property of the state.) In the view of the Waqf Administration and Kurbi the answer to the question of who owned the past in Turkestan was very clear - it was the local Muslim population. For Russian actors the answer was more ambiguous. Nechkin, for example, at times also emphasized local ownership, referring to "the people of Turkestan." ${ }^{109}$ Yet, on other occasions, according to Nechkin and other leading Russian preservationists, "the worldwide importance" (mirovoe znachenie) of Turkestan's monuments turned them above all into "the pride of Russian science," of "the Soviet state," or even of "all humankind." Therefore, a matter as significant as their preservation could not be left to the local population, but "should be considered by a top organ at the federal level" (i.e., Glavmusei of the RSFSR Narkompros). ${ }^{110}$

In this period, the bodies involved in preservation made claims about how the Soviet regime prioritized "the saving of Islamic monuments," "despite the civil war ravaging the young republic and massive problems related to the construction" of the new state. ${ }^{111}$ However, behind the facade of optimistic rhetoric stood a different reality. The leadership of Turkomstaris and the Samarkand Commission regularly had to admit that neither Moscow nor Turkestan's government were ever able to allocate sufficient funding for carrying out the most basic preservation work. Particularly during the famine

${ }^{106}$ A IIMK. F. 67. Op. 1. D. 27. L. 5.

${ }^{107}$ In October 1923, the government of Turkestan gave the Main Waqf Administration full control over how to spend the funding allocated for the preservation of buildings of a religious nature. Nechkin protested by arguing that Turkomstaris should have the final say about how such funding was used in relation to architectural structures classified as "monuments." A IIMK. F. 67. Op. 1. D. 27. L. 18.

${ }^{108}$ TsGA RUz. F. R-394. Op. 1. D. 32. L. 10.

${ }^{109}$ TsGA RUz. F. R-394. Op.1. D. 34. L. 85; F. 34. Op. 1. D. 1215. L. 73.

${ }^{110}$ A IIMK. F. 67. Op. 1. D. 27. L. 16ob-17. A meeting of Glavmusei on February 6, 1924, agreed with that view.

${ }^{111}$ TsGA RUz. F. R-394. Op. 1. D. 28. L. 442, and D. 3. L. 352.

102 
of 1922, some leading Bolsheviks in Moscow openly opposed spending any money on such an "insignificant matter" as monument preservation. ${ }^{112}$ A report by Turkomstaris on June 19, 1923, which noted that the lack of money and the consequent shortage of cadres "make it completely impossible to carry out even work related to surveying the state of local monuments," well captured what happened on the ground. ${ }^{113}$

Thus, in the period 1917-1924 the rhetoric of preservation of monuments of Islamic architecture as a priority of the revolutionary state clashed with the reality of the shortage of personnel, lack of funding, and different priorities of local revolutionary authorities. In the context of confusion and uncertainty no clear position was formulated regarding how to understand the relationship between different levels of the symbolic ownership of monuments (i.e., local, pan-state, or international). These levels of "ownership" appeared to be conflicting, rather than mutually reinforcing. Local authorities, members of preservation bodies and some top politicians in Moscow agreed that the state-sponsored preservation of monuments would improve the image of the Soviet regime in Turkestan, but the issue of what identities these monuments were expected to foster among the local population, or any other people who might be concerned with them, was not directly addressed.

\section{The Context of the National Delimitation}

The national delimitation of Turkestan that began in 1924, with the creation of the Uzbek and Turkmen Soviet Socialist Republics (SSRs), the Tajik Autonomous Soviet Socialist Republic within the Uzbek SSR and the Kara-Kirghiz Autonomous Oblast within the Russian Federation, ${ }^{114}$ had an enormous impact on the ideological underpinnings and administrative organization of monument preservation. Not only did the delimitation eventually lead to the abolition of a single Central Asian preservationist organization and a significant change in personnel, but it also signified a momentous intellectual shift. This shift amounted to the redefinition of the broad notion of "national culture."

In the context of carrying out the national delimitation of Central Asia, the issue of the administrative reorganization of cultural institutions of former

${ }^{112}$ TsGA RUz. F. R-394. Op. 1. D. 28. L. 331, 333.

113 TsGA RUz. F. R-394. Op. 1. D. 190. L. 27.

${ }^{114}$ The process of national delimitation was complex and prolonged, stretching over more than a decade until 1936. For more details, see Haugen. The Establishment of National Republics in Soviet Central Asia. 
Turkestan naturally arose. The replacement of the pan-Turkestan institutions by those specific to the newly created republics was a logical outcome of the creation of separate ethnonational political entities. In hindsight, the proposal to abolish the single Central Asian preservation body, now called Sredazkomstaris, and to replace it with separate committees for the preservation of monuments in each newly created republic looks inevitable. ${ }^{115}$ The Narkompros of Uzbekistan, the most dominant Central Asian republic, emerged as the main body lobbying for the abolishment of Sredazkomstaris. However, until October 1928, the leadership of Sredazkomstaris, with the help of the USSR Academy of Sciences, the Academy of the History of Material Culture in Leningrad, and the RSFSR Narkompros managed to protect Sredazkomstaris from being closed. Only in October 1928 did Sredazkomstaris cease to exist, whereas the largest part of preservation work in Central Asia began to be overseen by the Uzbek Committee for the Preservation of Monuments of the Past (Uzkomstaris). ${ }^{116}$ Other republics also gradually established their own committees. ${ }^{117}$

Why was this seemingly logical reorganization resisted for almost four years? The leadership of Sredazkomstaris, academics in Leningrad and Moscow, as well as the leadership of Glavmusei of the RSFSR Narkompros, all originally agreed that the shortage of cadres and resources simply made the establishment of separate preservation committees in each newly created republic unfeasible. The political elites of the newly created Central Asian republics initially agreed with this view. ${ }^{118}$ This was, however, only a secondary argument.

The main one related to a more abstract issue - understanding of the notion of "national culture." In the first four years after the delimitation, any attempt to abolish Sredazkomstaris was rebuffed by the argument that "the unity of cultural traditions of all Turkestan" required the existence of a single organ in charge of preservation. ${ }^{119}$ The culture of Turkestan was described in Sredazkomstaris's reports as owing its greatness "to the diversity of nationalities that have been mixing here" from ancient times. Thus ethnic mixing and multidirectional cultural exchanges contributed to turning former Turkestan into "a colossal archaeological treasure house,"

${ }^{115}$ Gorshenina. Turkomstaris. Pp. 60-63.

${ }^{116}$ The Uzkomstaris was finally established in April 1928 and started to receive funding from October of that year. TsGA RUz. F. R-2. Op. 1. D. 2. L. 5; D. 1. L. 27.

${ }^{117}$ Gorshenina. Turkomstaris. Pp. 63-65.

${ }^{118}$ TsGA RUz. F. R-394. Op. 1. D. 190. L. 49-50; A IIMK. F. 2. Op. 1. D. 82 (1928). L. 14.

${ }^{119}$ A IIMK. F. 2. Op. 2. D. 96 (1926). L. 23-23ob.

104 
it was suggested. ${ }^{120}$ "Current national borders of the new state entities," Sredzakomstaris stressed, "do not correspond to the borders of the previous life (granitsy proshloi zhizni) of the peoples of Central Asia." ${ }^{21}$ Not only Russians appointed by Moscow, such as Nechkin, or former imperial scholars such as Bartol'd, put forward this argument, but also the Central Asians who were placed in a position of power in Sredazkomstaris at the time of the delimitation, such as M. Kadyrov who became Nechkin's deputy in $1924 .^{122}$

The argument about Central Asia as a single cultural region, where cultural production was a result of centuries of interactions and mixing of various nationalities, reflected a particular vision of a "national culture" as, inevitably, a multiethnic endeavor, not a discrete, insulated entity, but a product of complex transnational communications. This transnational vision of culture emerged in Europe's intellectual tradition in the last decade of the nineteenth century as a reaction to Romantic nationalism of the earlier period. One can argue that this cultural vision was a product of European imperialism in an age of emerging national movements and that it was an attempt to reconcile tensions between empire- and nation-building impulses of the time. In the Russian empire this vision of "national culture" had powerful resonance because of its integrationist potential within the contiguous imperial space. At the turn of the twentieth century, the vision of "Russian national culture" as a product of centuries of activities of different nationalities that had been historically mixing (smeshenie) on the territory of the imperial state was promoted by several of the most prominent academics. ${ }^{123}$ Some of them applied the same view of culture to the empire's non-Russian domains, particularly the Caucasus and Central Asia. Nikolai Marr's works depicted the "Caucasian cultural world" as being shaped by the mixing of multiple nationalities, both Christians and Muslims, ${ }^{124}$ whereas Bartol'd subscribed to the vision of "a common Central Asian culture," which was also a result of ethnic mixing and multiple transnational cultural exchanges. ${ }^{125}$ These visions explicitly rejected the idea that any national culture

${ }^{120}$ TsGA RUz. F. R-394. Op. 1. D. 143. L. 51.

${ }^{121}$ TsGA RUz. F. R-394. Op. 1. D. 121. L. 1.

${ }^{122}$ A IIMK. F. 67. Op. 1. D. 24 (1924). L. 27. It has proved impossible to reconstruct Kadyrov's life and background from the available archival documents.

${ }^{123}$ Tolz. "Russia's Own Orient". Pp. 34-36. See an excellent development of this argument in Ilya Gerasimov, Sergey Glebov, and Marina Mogilner. Hybridity: Marrism and the Problems of Language of the Imperial Situation // Ab Imperio. 2016. No. 1. Pp. 27-68. ${ }^{124}$ Pravilova. Contested Ruins. Pp. 87-92; Tolz. "Russia's Own Orient”. P. 127.

${ }^{125}$ Tolz. "Russia’s Own Orient". Pp. 128-129. 
could have "a single ethnic root" and that any particular ancient artifact or monument could be identified with a single currently existing nationality. ${ }^{126}$

As for Central Asian intellectual elites, their definitions of national communities on the eve and in the immediate aftermath of the 1917 Revolution also differed from the type of narrow ethnic nationalism that influenced the 1924 delimitation. According to Khalid, the Jadids' definitions of the nation were territorial (in relation to a Bukharan nation), dynastic and religious (the nation of Muslims of Turkestan), or the nation of the entire Turkic population of Central Asia. ${ }^{127}$ So in 1924, "the Jadid hoped to retain the unity of Turkestan and Bukhara as homelands for a single Turkic Muslim nation." ${ }^{128}$ Following this logic, when in the first four years after the start of the delimitation, the Narkompros of Uzbekistan had been lobbying for the dissolution of Sredazkomstaris and the creation of the Uzbek Committee for the preservation of monuments, the Commissariat envisaged the latter to keep the same pan-Central Asian remit as Sredazkomstaris, embracing the entire former Turkestan, Bukhara (later part of the Uzbek SSR) and Khorezm (divided in 1924 between three newly created ethnic autonomies). ${ }^{129}$

Here the difference between identity politics in Central Asia and the Caucasus is evident. Narrow, ethnocentric definitions of national communities and cultures were articulated in the Caucasus by Armenian and Georgian intellectual elites well before the revolution. Some of their representatives openly clashed with Marr's vision of the pan-Caucasian cultural world already in the first years of the twentieth century, suggesting instead the appropriation of specific historical monuments for the production of separate Armenian and Georgian national histories. ${ }^{130}$ In the context of Central Asia, this clash was triggered by the start of the national delimitation in $1924 .{ }^{131}$

${ }^{126}$ Eadem. Pp. 34-36; Gerasimov, Glebov, and Mogilner. Hybridity; Pravilova. Contested Ruins. Pp. 87-92.

${ }^{127}$ Khalid. Nationalizing the Revolution. Pp. 156-8. ${ }^{128}$ Ibid.

${ }^{129}$ A IIMK. F. 2. Op. 1. D. 82 (1928). L. 11, 13.

${ }^{130}$ Pravilova. Contested Ruins. P. 95.

${ }^{131}$ See Khalid's analysis of F. Xo'jaev's concept of the Uzbek nation during the discussion of new national borders in the summer of 1924, which signifies a step toward a narrower ethnonational vision than earlier versions of national community in Central Asia. Yet even in 1924, Xo'jaev still attempted to embrace the entire sedentary Turkic population of Turkestan, thus offering a more inclusive and open definition of the nation than the later conceptions of nationhood. Adeeb Khalid. Uzbekistan: rozhdenie natsii // Neprikosnovennyi zapas. 2011. No. 4 (78). http://magazines.russ.ru/nz/2011/4/ha5.html (accessed February 16, 2016).

106 
It took time for the ethnocentric definitions of culture to be articulated and acted on in the area of monument preservation even after the new borders drawn along ethnic lines had been delineated in Soviet Central Asia. A clearly ethnocentric argument was finally made by the Uzbek SSR Narkompros in 1928 in a proposal to liquidate Sredazkomstaris and put the monuments under its auspices in the hands of the Uzkomstaris, which was about to be created. The Narkompros stated: "The overwhelming majority of monuments of antiquity and art in Central Asia are located on the territory of the UzSSR and therefore they are Uzbek monuments." ${ }_{132}$ Such a direct causal connection between the territorial location and ethnocultural belonging represented a new way of thinking.

In response, Sredazkomstaris's leadership repeated the position that had been commonplace among most preservationists and archaeologists since the turn of the twentieth century, namely, that the location of a particular monument on the territory of today's Uzbekistan did not make it an Uzbek monument and that any claim to this effect was ahistorical and, therefore, unscholarly. However, this argument no longer had the capacity to stop the processes of cultural reimagining that the national delimitation encouraged. ${ }^{133}$ The view articulated by the Uzbek Narkompros, according to which only the titular nationality could make a claim on the cultural heritage on the territory of the eponymous Union republic, from then on would start developing into a dominant Soviet position regarding the ownership of the past. ${ }^{134}$

The context of the national delimitation initially intensified public controversies around the work of preservation bodies. In 1924 and 1925 articles appeared in the local Uzbek press, arguing that repair and restoration of monuments could have been done more cheaply and quickly by indigenous craftsmen and that the existing preservation bodies had little to show for the funding that had been allocated. ${ }^{135}$ In turn, the Narkompros of Uzbekistan raised more boldly than ever before the issue of the return of historical artifacts that had been taken out of Central Asia by European and

${ }^{132}$ A IIMK. F. 2. Op. 1. D. 82 (1928). L. 13.

${ }^{133}$ Ibid.

${ }^{134}$ This point is argued by Gerasimov, Glebov, and Mogilner. Hybridity. This article dates the emergence of the narrowing ethnonationalisation and essentialization of the "scientific and social imagination" to the indigenisation (korenisatsiia) policy of the 1920s (see P. 47).

${ }^{135}$ TSGA RUz. F. R-34. Op. 1. D. 2627. L. 7, 70, 74; F. R-34. Op. 1. D. 2104. L. 124. The criticism was systematically refuted by the leaders of the Samarkand Commission and Sredazkomstaris. 
Russian scholars over the years. ${ }^{136}$ Such campaigns for returning "plundered treasures" have parallels in other postcolonial contexts. ${ }^{137}$ In most cases, however, as in the case of Central Asia, no mass-scale return has ever taken place.

Further calls were made by both the authorities of Uzbekistan and the leaders of preservation bodies about the need to involve more representatives of the indigenous population in preservation. Both sides agreed that "future successes of our work ... could only be achieved with the participation of Eastern nationalities. The more representatives of the native population will take part, the more successful our work will be." ${ }^{\text {138 }}$ Sredazkomstaris and the Samarkand Commission began expressing a greater interest in employing local craftsmen who used "traditional methods" in restoring ornaments on ancient mosques. Significantly, their involvement continued to be justified through references to the positive experience of such collaboration in British India. ${ }^{139}$ The superiority of the European approaches to preservation through conservation, rather than rebuilding, also continued to be emphasized by Sredazkomstaris. In the ongoing promotion of conflicting narratives, "local craftsmen" were simultaneously criticized for using "crude and primitive methods" (grubym kustarnym methodom), which "destroyed" a monument by "depriving it of its historical value." 140

Yet, despite the appearance of greater public controversies around approaches to preservation that seem to have continued to contrast Russian and indigenous attitudes and interests, within the preservation bodies, Russians and newly appointed Central Asians paradoxically seemed to have worked with far fewer tensions than what we observed during the involvement of Kurbi in the early 1920s. This was likely because Russian preservationists and Jadids who became the main new participants in the work of the official preservation bodies in the context of the delimitation, shared more common assumptions about the purpose of preservation than took place in the case of Kurbi. In this new context, particular praise in the official Sredazkomstaris reports on preservation was allotted to activities in locations where leading preservationists were not Russians, but local Jadids. This was in Bukhara,

\footnotetext{
${ }_{136}$ TsGA RUz. F. R-394. Op. 1. D. 143. L. 35.

${ }^{137}$ Swenson. Introduction. P. 15. See also James Cuno. Who Owns Antiquity? The Battle Over Our Ancient Heritage. Princeton, 2008.

${ }^{138}$ A IIMK. F. 2. Op. 1. D. 96. L. 5ob.

${ }^{139}$ TSGA RUz. F. R-394. Op. 1. D. 143. L. 89; TsGA RUz. F. R-394. Op. 1. D. 188. L. 22.

${ }^{140}$ TsGA RUz. F. R-394. Op. 1. D. 143. L. 89.

108
} 
where a local preservation commission was set up in 1925. The discussion about setting up a Bukharan preservation body began back in 1923-1924 in Moscow, with the involvement of Xo'jayev and another Bukhara Jadid, Musa Saidjonov. The first chairman of the commission, which began its work in 1925, was Abdurauf Fitrat, a leading Jadid intellectual who articulated the notion of Timur as the founding father of the national community of Central Asian Turks. ${ }^{141}$ Later the same year Fitrat was replaced by Saidjonov, who emerged as a leading preservationist. ${ }^{142}$ In 1928, Saidjonov first became Viatkin's deputy in the newly established Uzkomstaris, later in the year swapping roles with Viatkin and becoming the organization's chairman. ${ }^{143}$ Despite the start of Stalin's new "revolution from above" and a new antireligious campaign, which this time also targeted Islam and involved the destruction of regional mosques, Uzkomstaris's reports, which Saidjonov and Viatkin were sending to academic institutions in Leningrad until 1932, were written in a style surprisingly similar to that of the previous period. Most of the discussion was about the technical side of preservation, and "monuments of Islamic architecture" continued to be the main focus of Uzkomstaris's activities. ${ }^{144}$

The year 1932 marked another turning point in the politics of memory in Central Asia. That year witnessed the consolidation of independent republican preservation committees, as they became much less connected with academic circles in Leningrad and Moscow; cooperation in preservation between Central Asian republics also decreased. Rather than representing a common Central Asian past of interethnic mixing and multidirectional influences, the monuments could now be fully appropriated in the writing of separate ethnocentric national histories for each republic of Soviet Central Asia.

This further shift in the ideological underpinning of preservation activity in the early 1930s was exacerbated by the change in personnel due to purges. Campaigns aimed at replacing those in cultural institutions who were representatives of the prerevolutionary intelligentsia with those trained under the Soviet regime began in 1926-1927, significantly intensifying by the end of the decade. In 1930-1932, some members of the preservation bodies from among Russian experts with a prerevolutionary background, such as Aleksandr Semenov, Aleksandr Schmidt, and Ivan Umniakov, were arrested in

${ }^{141}$ On Fitrat's role, see Khalid. Making of Uzbekistan. Pp. 66-69, 258-264.

${ }^{142}$ See the description of his activities in A IIMK. F. 2. Op. 1. D. 96 (1926). L. 5ob.

${ }^{143}$ Gorshenina. Turkomstaris. P. 64; Eadem. Musa Saidzhanov. Pp. 27-28.

${ }^{144}$ A IIMK. F. 2. Op. 1. D. 119. L. 3-26ob; F. 2. Op. 1. D. 768 (1931). L. 1-20. 
a campaign against "bourgeois historians." 145 A campaign targeting Jadids was also launched. ${ }^{146}$ In 1932, Saidjonov was arrested. ${ }^{147}$

At a time of increasing repression, the main cleavage emerged between (usually younger) individuals trained under and devoted to the new regime and those who cooperated with Soviet power without sharing all its values and retained a strong commitment to approaches and assumptions of the prerevolutionary era. The latter were "bourgeois" historians such as Schmidt and Central Asian Jadids, such as Saidjonov and Fitrat. A prime example of the former was Mikhail Tsvibak, who in 1926 replaced Nechkin as chairman of Sredazkomstaris. A member of the Bolshevik Party since 1918 and a lecturer in the Leningrad branch of the Communist Academy, Tsvibak was sent to Tashkent with the task of carrying out a purge of "bourgeois" cultural figures, including those involved in preservation. In 1927, he embarked on the task with great zeal, accusing those "trained before the revolution" of using "outdated methodologies" instead of the "class approach and materialism." 148

During these purges of cultural institutions from "bourgeois" intelligentsia with prerevolutionary backgrounds, the rationale behind preserving ancient monuments, particularly buildings of a religious nature, was questioned. In a report, sent to the Academy of the History of Material Culture about the Uzkomstaris's activities in 1929-1930, chairman Saidjonov and his deputy Viatkin noted with alarm:

During the purge of the apparatus of the People's Commissariat of Enlightenment of the UzSSR one comrade participating in the discussion said something along the lines: "What benefit is there for us in preserving such ruins (razvaliny); we are wasting a lot of money to no avail." He continues, "When I spend time around these monuments, various mystical thoughts enter my mind." 149

Saidjonov and Viatkin were particularly concerned that this statement, which they described as "not only unacceptable, but politically harmful today," failed to receive a proper rebuttal at the time. ${ }^{150}$ Yet the public ex-

${ }^{145}$ Their subsequent situations differed. Released after the end of the cultural revolution, some continued their careers, escaping further purges. Others, such as Schmidt, perished during the Great Terror. See also Valerii Germanov. Vostochnyi front // Vostok-Oriens. Afro-aziatskiye obshchestva: istoriia i sovremennost'. Moscow. 1996. No. 3. Pp. 115-137. ${ }^{146}$ Khalid. Making Uzbekistan. Pp. 321-328.

${ }^{147}$ Gorshenina. Musa Saidzhanov. P. 29.

${ }^{148}$ TsGA RUz. F. R-394. Op. 1. D. 261. L. 95-7, 99-102.

${ }^{149}$ A IIMK. F. 2. Op. 1. D. 768 (1931). L. 19.

${ }^{150}$ Ibid. 
pression of such dismissive views about preservation notwithstanding, the Council of People's Commissars of Uzbekistan allocated more funding for preservation in 1929/1930 than in the previous three years. ${ }^{151}$ Furthermore, in 1929, archaeological work on the main ancient site of Afrasiab in Samarkand reportedly expanded considerably.

How was this possible? Uzkomstaris's reports acknowledge the role of Xo'jayev, appointed chairman of the Sovnarkom of Uzbekistan in 1925, as an important patron of preservationist activities, who occasionally personally took the initiative to allocate funding for preservation projects. ${ }^{152}$ The "scientification" of monuments further helped to justify the position that the preservation activities were an important part of constructing a new Soviet identity and an effective tool to mobilize the population in support of the Soviet regime. In the new context of intensified Sovietization of the cultural sphere, the discursive process of stripping monuments of the past of their religious nature, representing them as mere historical evidence and secular museum exhibits, was foregrounded. As mentioned above, this approach to monuments originated before the 1917 Revolution and it was championed by preservation experts across Europe. From 1925 onward, the political sensitivity of the issue was fully spelled out during meetings of the preservation committees, with Russian and Central Asian participants articulating similar positions. It was argued that treating religious objects and sites as "any museum exhibit" and providing them with explanatory notes about their origins, written by academic experts "in a simple style in the Uzbek language" would effectively prevent them from being used "for exploiting religious feelings of the masses," turning them instead into a tool "of the struggle against superstitions."153

The preservation of "historical monuments" was thus expected to serve as an instrument to facilitate what Hirsch called "double assimilation," the core principle of the Soviet nationalities policies as they crystallized in the 1920 s. ${ }^{154}$ The process was supposed to start with the assimilation of people into nations, understood largely in ethnocultural terms, as the first step toward the goal of assimilating citizens of different ethnic origin into the

${ }^{151}$ Between 1926 and 1928, the uncertainty around the organizational structure of the main preservation bodies drastically reduced the already meager funding. The funding figures for the period from 1926 onward are cited in the Uzkomstaris report for 1929/1930. A IIMK. F. 2. Op. 1. D. 768 (1931). L. 6.

${ }^{152}$ A IIMK. F. 2. Op. 1. D. 119 (1928-1930). L. 12.

${ }^{153}$ A IIMK. F. 2. Op. 1. D. 96 (1926). L. 5-6ob.

${ }^{154}$ Hirsch. Empire of Nations. Pp. 146-147. 
Soviet whole. However, as the extensive scholarship on Soviet nationalities policies has noted, the Soviet regime never spelled out the ways in which this double assimilation was supposed to work in practice. ${ }^{155}$ This is evident in the area of monument preservation. Discussions over the creation of preservation committees within the newly created Central Asian republics did not even consider how the old sites, now to be understood as having a single ethnonational affiliation (e.g., Uzbek), were simultaneously supposed to function as Soviet monuments. The long-term implications of the capacity of these reimagined monuments to foster separate ethnonational identities, rather than the overarching state-framed one, were not reflected on. ${ }^{156}$

\section{Conclusions}

In the course of the nineteenth century, the politics of historical memory emerged as such a crucial element in forging new collective identities that the Soviet regime as an heir to European modernity inevitably embraced for its own purposes some key tools of these politics. One of them was the preservation of historical monuments. Since the late nineteenth century, Russia's preservation bodies operated under the influence of pan-European policies and practices in this area. Rather than contrasting Russia and the West in the area of preservation, the former, including during the Soviet period, should be studied as an integral part of the emerging global sphere of transnational and transimperial transfers of discourses and practices of preservation. The continuity of personnel from the tsarist into the Soviet period further ensured that modern European ideas about preservation began to shape Soviet approaches. In the postrevolutionary years, collaboration between actors with different political views was eased by the common strategy of the "scientification" of monuments. This deprived old architectural structures and artifacts of the values that the Soviet regime found objectionable, above all religious values. The fact that buildings and objects, used for religious services, were perceived as "historical monuments" allowed their inclusion in the cultural heritage for which the Soviet state was expected to care.

${ }^{155}$ See, in particular, Rogers Brubaker. Nationhood and the National Question in the Soviet Union and Post-Soviet Eurasia: An Institutional Account // Theory and Society. 1994. Vol. 23. No. 1. Pp. 47-78.

${ }^{156}$ The weaknesses of the Soviet Union's strategies to create an overarching Soviet identity have been extensively analyzed. See, in particular, Brubaker. Nationhood and the National Question. Pp. 47-78. 
At the time of the intensification of states' involvement in preservation, Europe's colonial domains emerged as very significant loci in developing new approaches to the past that the European states claimed as their cultural heritage. In Russia this was particularly strongly the case because the colony of Turkestan was proclaimed to possess the empire's greatest cultural treasures. Transfers of discourses and practices between the colonizers and the colonized thus became important to developing the state's preservation policies. In the first postrevolutionary decade, Turkestan appeared as the site of the most intense activities around preservation, where the colonial conceptual apparatus and policies coexisted in a contradictory amalgam with the new regime's anti-imperial proclamations and initiatives. It is in this contradictory environment that the national delimitation of Central Asia began in 1924. Its ethnocentric logic engendered, at times unwittingly, a major ideological shift. It amounted to replacing the transnational and multiethnic understanding of cultural production, as articulated in the last decades of the tsarist era, with the ethnocentric understanding of national cultural. It is the way in which "culture" was understood that marked the single most important difference between the discourse of preservation in the late imperial era and the Soviet era. Irrespective of how much the Soviet government used the ethnographic data supplied by former imperial scholars in carrying out the national delimitation, some of these scholars' main intellectual assumptions were repudiated by the delimitation policy. In fact, in his criticism of the delimitation, a leading representative of the imperial scholarship, Bartol'd, admitted as much. ${ }^{157}$ Nor did the new understandings of the nation and its culture fully coincide with the views that Central Asian Jadids had been elaborating prior to and in the immediate aftermath of the 1917 Revolution. The ideological shift correlated with the change in personnel involved in preservation. By the early 1930s, preservation bodies in the region began to be dominated by those trained under the Soviet regime, among whom were now a much greater number of "indigenous" cadres. Both the pre- and post-1924 approaches to preservation were aimed at maintaining the territorial integrity of the state, but none ultimately resolved the conflict between empire- and nation-building impulses of the time.

${ }^{157}$ In 1924, Bartol'd wrote a strong critique of the delimitation policy, arguing that it ran counter to cultural and historical traditions of the region. Zapiska ak. V. V. Bartol'da po pravitel'stvennomu zaprosu v sviazi s national'nym razmezhivaniem // A RAN (SPb). F. 86. Op. 1. D. 79. L. 1-2. 


\section{SUMMARY}

The article analyzes discourses and practices of historical monument preservation in Early Soviet Central Asia. Already at the turn of the twentieth century, Russian activists and scholars engaged in preservation work regarded Turkestan as the main archaeological treasury of the empire. In the sources they analyze the authors debunk a widely accepted view of the preservation work as a rare venue for apolitical cultural activity of the intelligentsia that tried to disengage itself from ideological service to the regime. The authors claim that, contrary to this view, the Soviet regime in Turkestan made preservation of the ancient Islamic architecture one of its most important instruments of propaganda and population mobilization. In this regard, the regime broadly relied on experts who had been involved in this work well before the revolution.

The article compares discourses and practices of monument preservation in the late imperial and early Soviet periods, and studies the influence on them of broader European debates at the time about "historical heritage" and its reconstruction. This comparison shows that preservation work was always perceived in the region as part of imperial and then Soviet integrationist projects, and as such provoked multiple conflicts both locally and in the capital. The turning point in the ideological reappraisal of the role of monuments of Islamic architecture came neither with the Revolution of 1917 nor after the official establishment of Soviet power in Turkestan in 1920. Not until the beginning of the process of national delimitation in Central Asia in 1924 did local interest in cultural preservation gain momentum. Between 1928 and 1931, national committees for monument preservation were established in every newly founded Central Asian republic. This development institutionalized the profound transformation of transnational cultural imagination that had been formed by the early twentieth century into a new, ethnocentric understanding of "culture."

\section{Peзюne}

В статье анализируются дискурс и практики охраны исторических памятников в Средней Азии в раннесоветский период. Уже на рубеже $\mathrm{XX}$ в. российские деятели, вовлеченные в охрану памятников старины, провозгласили Туркестан главной археологической сокровищницей империи. Анализируемые в статье источники демонстрируют, что, 114 
вопреки распространенному мнению, после революции 1917 года охрана памятников в разных регионах бывшей империи не превратилась в отдушину для аполитичной культурной работы представителей интеллигенции, пытавшихся держаться в стороне от идеологических требований нового режима. Напротив, советский режим сделал охрану памятников исламской архитектуры в Туркестане одним из важнейших орудий пропаганды и мобилизации населения при широком участии тех, кто был вовлечен в эту деятельность еще до революции. В статье сопоставляются дискурсы и практики охраны памятников в позднеимперский и раннесоветский период и анализируется влияние на них общеевропейских тенденций в области конструирования исторического наследия. Сравнение отношения к памятникам российских экспертов и населения региона показывает, что охрана памятников воспринималась как орудие имперской и общесоветской интеграции, вызывая многочисленные конфликты как на местном уровне, так и в центре. Поворотным в идеологическом переосмыслении памятников оказался не 1917 г. и не провозглашение советской власти в Туркестане в 1920 г., а начало национального размежевания региона в 1924 г. Между 1928 и 1932 гг. создаются отдельные национальные комитеты по охране памятников новых среднеазиатских республик. Произошедшая перемена в дискурсе о памятниках имела огромные идеологические последствия, коль скоро на смену транснациональному восприятию культурных процессов, сформировавшемуся на рубеже XX в., пришло этноцентричное понимание “культуры”. 